\title{
A Teoria da Melancolia em Walter Benjamin A versão do taedium vitae medieval e de seus elementos teológicos na concepção de melancolia do barroco
}

\author{
Tereza de Castro Callado*
}

\begin{abstract}
Resumo: A versão do taedium vitae na teoria da melancolia do século XVII barroco agrega elementos originários da antiguidade clássica do tratado aristotélico De divinatione Somnium através do Renascimento, em que a genialidade melancólica desses teoremas em torno da bílis negra (atra bilis) enriquece a teoria do dualismo fundamental da melancolia como manifestação, por um lado, da apatia, por outro, do dom divinatório que produz os religiosi contemplativi e aqueles que estão predestinados, por Saturno, ao sonho profético, entre os quais figuram mártires e príncipes.
\end{abstract}

Palavras-chave: taedium vitae, acedia, saturno, religiosi contemplativi, profecia, spleen.

\begin{abstract}
The version of the taedium vitae in the seventeenth century Baroque melancholy aggregates elements from classic antiquity, through Renaissance, in the Aristotelian treaty De divinationem Somnium, in which the melancholic geniality of these theorems around the black bile enriches the teory of the fundamental dualism of melancholy as a manifestation on one side, of apathy, and on the other, divinatory talent that produces the religiosi contemplativi, and those that are pre-destined by Saturn for prophetic dream, among which are the martyrs and princes.
\end{abstract}

Keywords: taedium vitae - acedia - saturn - religiosi contemplativi - prophecy - spleen.

\footnotetext{
* Tereza de Castro Callado, Doutora em Filsofia e em Literatura Brasileira pela Universidade De São Paulo, é Professora do Departamento de Filosofia e do Curso de Mestrado Acadêmico em Filosofia da Universidade Estadual do Ceará.
} 
Se o sono é o ponto mais alto da distensão física, o tédio é o ponto mais alto da distensão psíquica. $O$ tédio é o pássaro de sonho que choca os ovos da experiência

O Narrador - Walter Benjamin

Com o fim do tédio desaparece o dom de ouvir e desaparece a comunidade dos ouvintes. (Os ninhos do tédio) já se extinguiram na cidade e estão em vias de extinção no campo.

Benjamin.

Tempos sombrios (finstere Zeiten) - com essa expressão Hannah Arendt qualifica a época em que viveram Walter Benjamin, Brecht, Jaspers, Rosa Luxemburgo... Tempos Tardios (Spätzeit) é o selo cunhado por Walter Moses para referir-se ao cansaço que anuvia a atmosfera moderna. Já Baudelaire, na triste pujança do poema Spleen de Les fleurs du mal, descreve a ruína do seu tempo na consciência esmagada entre moral cristã e pagã. Nos casos citados, a melancolia, quer movida pela sensibilidade de poeta ou se apresente como um novo mal du siècle, parece reinar soberana, venha ela do mundo exterior ou brote da predisposição do temperamento, na mais profunda interioridade do ser. Com o trabalho filológico sobre o drama barroco (Trauerspiel) em Origem do Drama barroco alemão (Ursprung des deutschen Trauerspiels) Benjamin já pressente, na "forma tosca" da estética seiscentista, o germe da "especulação" criativa que tem seu correlato na linguagem fragmentada, aspirando ao desabrochar na sua pós-história, ou seja, na salvação psicanalítica da palavra. Tédio e melancolia representam uma resposta ao tratamento fragmentário sobre o conhecimento, formalizado na fundação de teorias e princípios de toda ciência moderna que encontra sua origem em um desvio retrabalhado por Benjamin no projeto filológico de retorno ao seu ponto fulcral, na contramão da história da civilização, considerada por ele como uma rua de mão única (Einbahnstrasse). A metodologia benjaminiana segue assinalando as distorções observadas pela historiografia inconsciente presente no conteúdo de verdade (Wahrheitsgehalt) do belo, inscrito na obra-de-arte e na linguagem nomeadora. Repara e minimiza as distorções conceituais na medida em que as idéias ao nomearem os fenômenos, são, por sua vez, reconhecidos por elas. Seu objetivo é corrigir um universal apenas retirado da média. Uma vez "salva", a idéia libertará o conceito contra as estereotipias que minam a reflexão com generalizações por distorção ou falseamento, confundindo-o e gerando preconceito a sua volta, o que podemos exemplificar no vocábulo "maquiavélico", "homem barroco", "homem renascentista" ou "cartesianismo" conceitos que "capengam" a verdade filosófica. Para Benjamin o "dualismo corpo e alma de Descartes, por exemplo, não constitui seu único elemento barroco". Benjamin se ocupa de várias maneiras desse fenômeno e o compreende como um estado de espírito que dissemina a mentalidade da ambivalência geradora da melancolia no olhar sobre o mundo exterior, investigando sua primeira exteriorização na percepção estética da arte. A poesia de Baudelaire encontra a expressão desse esfacelamento na cultura e a exibe no spleen. Na poesia baudelaireana Benjamin constata a geração do tédio na vida moderna. A origem dessa motivação ele a encontra no Trauerspiel, doravante considerado pré-história daquela poética. A dramaturgia do século XVII vê na melancolia a projeção da marcha da civilização como uma catástrofe contínua - idéia revelada através do trabalho filológico do drama exibindo nas suas 
entrelinhas os limites da criatura. Eles são teorizados na metáfora da face de Janus do Monarca que traduz o binômio tirano-mártir da cena barroca da corte. Essa interpretação é possível na medida em que o filósofo relata a ação do homem na concepção de uma imanência entre história e natureza, onde fica estampada a facies hippocratica da civilização. A transposição da vida orgânica para o espaço da história explica a suscetibilidade à degenerescência do orgânico que constitui a paixão do barroco. A inclusão, no mundo da vida, do processo histórico, é feita na dinâmica do auto-aniquilamento, concebido como destino (Schicksal). Fica explicada a exacerbação da melancolia ali enraizada nas contingências temporais, sem que seja abandonado o aspecto soteriológico da atmosfera pseudo-profana que atravessa a obra de arte do período barroco. No Trauerspiel a melancolia constitui a desolação da alma diante da inexorabilidade do destino. A apatia resultante desse sentimento, a sensação de inutilidade do esforço do homem, das coisas no seu entorno predispõem $o$ temperamento melancólico, no máximo, ao jogo, fazem dele a mentalidade de uma era que sucumbe desmotivada da ação, uma vez que ela é reprimida pelo rigor das novas teorias da Reforma Religiosa. A idéia de atemporalidade paradisíaca ou de uma suspensão do tempo, desenvolvida por essa época, faz contraponto à pressão de um destino privado de transcendência e repercute na representação panoramática da história do Trauerspiel, liderada pelo inconsciente, pela dissolução dos limites entre presente, passado, como um desvio da pressão do mundo finito e exalado no sentimento de fugacidade e efemeridade das coisas. A leitura barroca da melancolia enquanto sentimento natural do homem motiva a saída no artifício que se realiza na estética cênica do drama da alegoria, como expressão da convenção da época e não enquanto "convenção de uma expressão". Esse expediente inclui no seu conceito a constelação de idéias políticas que estruturavam o sistema jurídico do principado barroco, como a noção de estado de exceção, e por isso mesmo esse arcabouço conceitual não deixa de ser constituído de alteridade. Como pós-história do barroco, o expediente lingüístico utilizado por Baudelaire imprime no tédio, na mitomania, no deslocamento de significações, enfim no spleen, a percepção de uma cultura em decadência. Ela se fixa à deliqüescência dos valores, da mesma forma que a alegoria barroca se fixa às ruínas, que Benjamin quer ler como runas ${ }^{1}$, ou seja, fragmentos que contêm, como um enigma, a história de um indivíduo ou de um povo. Em Baudelaire o spleen constitui categoria de sua estética na forma de esgrimir com a realidade: "jogos de azar, flanar, colecionar são atitudes que se contrapõem ao spleen". Já na estética barroca, o jogo, evoluindo para o lúdico, aliena o destino no carpe diem - momento fugaz de fruição, dispersão, no instante, da exigüidade do tempo, da dor inerente à criatura na condição de mortal. Pois o luto é parte constituinte do estado de espírito barroco, no prolongamento de um mundo esvaziado do divino, que só se satisfaz através do enigma constituinte desse mesmo luto. Na obra arquitetônica do seu tempo "a construção representa o papel do subconsciente", ${ }^{2}$ talvez como uma forma objetivada de reconstruir o mundo através de materiais sólidos como o ferro. Já na antecipação do spleen de Baudelaire desenvolviase, no barroco, a arte geomântica da melancolia (adivinhação do desenho de um punhado de areia lançado sobre um tabuleiro), pois perdida a transcendência, a terra

\footnotetext{
${ }^{1}$ Runas são pedras com desenhos encontradas em escavações, sobre o solo ou imersas nas águas geladas da Escandinávia que decifradas carregam a histórias das gerações daqueles rincões e de seus líderes e príncipes bem como de suas formas de existência, séculos afora. Eram atribuídas igualmente a essas pedras poderes mítico-mágicos.

${ }^{2}$ Siegfried Giedeon. Bauen in Frankreich. Leipzig, 1928, p. 3. apud Obra das Passagens (Org e Trad. Willi Bolle), Sâo Paulo, Humanitas, 2006, p. 40. Da mesma forma as construções sobre as estruturas de ferro são uma marca inconsciente da instabilidade psicológica desse tempo.
} 
constitui o reduto último do homem e o olhar às profundezas da terra evoca a premência de uma explicação para a forma enigmática como a realidade se apresenta para aquela mentalidade criadora da poesia pastoral. Nela encontra-se a antítese do sentimento de abandono que afeta o homem barroco do século XVII para o qual o Trauerspiel constitui a cena por excelência. A poesia pastoral nascida do gesto de "lançar sementes ao solo materno" significa no mínimo apostar na possibilidade de que alguma germine. Pois a existência é enigma (Rätsel) e está mergulhada na idéia de natureza orgânica, concretizando o pensamento de que o "espírito é a faculdade de exercer a ditadura", para mostrar através da metáfora da separação entre eterno e transitório, ou entre a matéria e espírito, que só a natureza é exemplar: é dela que os dramaturgos como Opitz, Hallmman, Gryphius, Lohenstein e Haugewitz retiram seus modelos em forma de simbologias. Os recursos e dispositivos naturais justificam a história da humanidade, explicam o temperamento do homem e as vicissitudes da civilização. Nessa concepção em que se combinam os dois elementos na "imanência" história - natureza, a aspereza do espírito analítico, ligado ao detalhe e ao pormenor da dramaturgia barroca é desvelado na melancolia. Benjamin observa, da antiguidade clássica, os elementos originários da argamassa simbólica que irá estruturar a alegoria para representação desse teatro. Seu esforço na acumulação, a riqueza de signos depurados ao longo dos séculos e associada à contemplação apaixonada do barroco sobre a organicidade não abrem mão da precisão dos elementos indispensáveis à concepção de marcha da civilização humana como drama, levado às últimas conseqüências na idéia da sucessão de catástrofes que reflete as relações de poder, das quais a configuração do tirano absolutista é exemplar. O Trauerspiel não pode prescindir de uma explicação plausível relacionada a elementos constituintes que estão na origem da contradição e da ambivalência barrocas para explicar a si mesmo. É dessa argamassa que é feito o barroco: tempo cindido na aspereza da disciplina ascética, sem direito a expressar sua voz no sagrado, e por isso mesmo exteriorizada no profano, tempo esmagado na incógnita para a qual o racionalismo aprendido com Sócrates não apresenta nenhuma solução, tempo enclausurado no rigor das idéias de Lutero, pressionado pela ordem, pela obsessão do limite, apesar de aspirar ao movimento, à dissolução das fronteiras, à idéia de uma atemporalidade paradisíaca. Por um lado, a idéia clara e distinta de Descartes revela a mathesis universalis, induz o cálculo e a geometrização do espaço a realizarem a política num eterno sempre igual; por outro, a dispersão apreendida nas vicissitudes da existência, a disposição, pela experiência do movimento, à oscilação e desagregação da realidade entrincheirada na catástrofe histórica, anunciadoras de uma transgressão, por parte do príncipe barroco ao conceito de soberania vigente, geram a profusão de idéias e concepções dessa estética. A riqueza do barroco está na idéia afixionada de um saber que não liberta, e por isso responsável pelo acervo vultoso das grandes bibliotecas, na idéia que compreende o mundo como um imenso livro a ser lido, mas que permanece mais em um "querer" do que em um "fazer". O barroco não encontra consolo a não ser nos desvios para o apaziguamento da dor humana, nos pequenos jogos, no ludismo da poesia pastoral... Nos pequenos, ele aprofunda a interioridade que faz da época uma era de "hegemonia cristã incontestada", nos grandes gera a melancolia. Os personagens do drama oscilam entre a ira, a tirania, a fleugma, a doçura, a virtude. Chega-se ao humor melancholicus como chave para a "inclinação à inveja, avareza, medo, ganância e à cor terrosa do melancólico...” Diz Benjamin que "a patologia dos humores via a causa dessas características no excesso do elemento seco e frio dentro do organismo. Esse elemento era a bílis negra -bilis innaturalis ou atra, em 
contraste com a bílis antralis ou cândida. Da mesma forma que o temperamento úmido e quente se baseava no sangue, o úmido e frio (fleumático) se baseava na água ${ }^{3}$, e o seco e quente (colérico) se baseava na bílis amarela". A bílis negra é formada no baço, órgão vulnerável à tristeza. Ali a produção de sangue "grosso e seco" age diretamente sobre o humor, inibindo o riso e estimulando a hipocondria. Dessa forma o cão é um dos signos para explicar a vulnerabilidade do baço a esse temperamento. Sua fidelidade o deixa figurar como um sinal do divino entre os símbolos da pedra e da esfera que garantem a estabilidade e a segurança numinosas, para além do sentimento de acedia gerador de instabilidade. Não podia deixar de influenciar os eruditos nem impressionálos a contribuição do conhecimento das ciências empíricas do século XVII que flui para explicar as vicissitudes da criatura e a miséria da condição humana. Nem se pode negligenciar, neste diagnóstico, o arsenal de informações do período renascentista que presenteou ao ocidente a chave da antiguidade clássica. Ainda perscrutando o Renascimento, Benjamin vai encontrar na gravura Melencolia I de Albrecht Dürer uma visão de mundo onde os dramaturgos do barroco encontram os seus epígonos. É a conjunção de elementos astrológicos construindo uma unidade para a gravura que, se não é capaz de equilibrar o temperamento melancólico, vai, pelo menos, neutralizar sua sujeição à apatia, com a predisposição a lucidez ${ }^{4}$ e à descoberta do novo. A figura de uma mulher alada encontra-se cercada por objetos produzidos pelo engenho da ciência, e no entanto nenhum rasgo de curiosidade move a imagem. Ela jaz aterrorizada, como demonstra o olhar terrificante e o semblante torturado pela reflexão (Grübeln) sobre a inutilidade dos objetos que a rodeiam ${ }^{5}$.

Apesar de alada a mulher não parece pretender remover-se. Na sujeição à estaticidade, a figura é desafiadora. Ela parece desconhecer a linguagem daqueles objetos pretendendo constituir signos. Dessa forma ilumina o quadro a alegoria da perda, da ausência de sentido. É ainda a alegoria buscando signos em outro lugar "sem com isso evitar a "arbitrariedade" como manifestação extrema do poder do conhecimento ${ }^{6}$. Essa idéia da fragilidade das coisas foi teorizada, ainda no ocaso da Idade Média, por Marcílio Ficino, que preparou a concepção de melancolia para a

\footnotetext{
3 “Le sang imite l'air, augment au printemps, règne dans l'enfance. La bile (jaune) imite le feu, augment en été, regne dans l'adolescence. La mélancolie (ou bile noire) imite la terre, augment em automne, régne dans la maturité. La flegme imite l'eau, augment em hiver, règne dans la vieilleuse". KLIBANSKY, Raymond, SAXL, Fritz, PANOFSKY, Erwin. Opus cit. p.32 A caracterização do ar como elemento frio e a terra como elemento seco, da água como sendo úmida tem uma origem muito rêmora, ela vem das teorizações de Philistion - chefe da escola de medicina siciliana fundada por Empédocles - sobre a

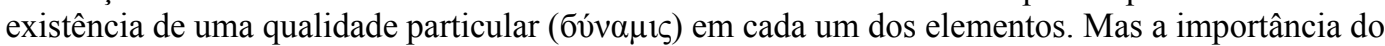
número quatro nesse contexto tem seu nascimento entre os pitagóricos. Neles encontramos não só a raiz da perpetuação da vida mas o equilíbrio cósmico que produz o homem racional organizado na matéria através das categorias tetrádicas situadas no cérebro, coração, umbigo e falo. No entanto os pitagóricos não elaboram nenhuma doutrina dos quatro humores. KLIBANSKY et allii, Opus cit.p. 33.

${ }^{4}$ Para Cícero, nas suas reflexões sobre o estoicismo, o que importa na análise da melancolia, é a separação entre sabedoria e loucura, distinção que nem sempre aconteceu na concepção dos antigos. Ele traduz o grego melancholia por "furor", vocábulo para designar as convulsões e paixões a que sucumbem os que são afetados pela atrabilis. Daí conclui-se que o homem sábio nunca será afetado pela loucura, o que não o livra incondicionalmente do delírio ou da alucinação.

${ }^{5}$ A originalidade do desenvolvimento da descoberta de um número astrológico gerador de equilíbrio se deve a Filolau. Ele descrevia com o número quatro o princípio do corpo saudável, o que é bastante inventivo, pois normalmente, na tradição das primeiras especulações sobre o temperamento melancólico, o sistema médico e o astrológico permanecem separados. KLIBANSKY, Opus cit, p. 33. Até muito tarde Paracelso só reconhecia na astrologia o constituinte desse temperamento. Ainda no ocaso da Idade Média ${ }^{6}$ BENJAMIN. ODBA, p. 206. Ursprung. Opus cit. S. 162.
} 
Modernidade ${ }^{7}$, agregando ao conceito uma idéia positiva. Ficino dá a dosagem certa de elementos para o equilíbrio do corpo ${ }^{8}$. Principalmente a obra De vita tríplice é responsável pela justa valorização desse humor determinado pela bílis negra. Mas, ainda nos tempos modernos a interpretação da melancolia sofre mudanças ${ }^{9}$. E as variáveis que estabilizam o sentimento eclodido na desagregação inerente a Physis, na concepção seiscentista da estética barroca e recolhida pela melancolia, evitando a oscilação inerente ao espírito contraditório da criatura, é representada na gravura de Albrecht Dürer, por um quadrado sinalizando a ação de Júpiter. Essa argúcia de espírito tem uma origem. $\mathrm{Na}$ antiguidade clássica Aristóteles, por exemplo, diz que os homens que possuem sabedoria prática, são homens de ação ${ }^{10}$. Nas Problema $(30, \mathrm{I})$ atribuídas a ele, a bílis negra (melaina kole) determina os grandes homens.

A melancolia sempre mereceu um lugar nas reflexões de diferentes filósofos dentre os mais remotos tempos. Na literatura dos antigos o tratado sobre a estrutura

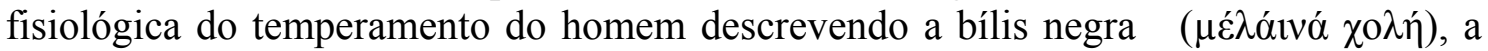
fleuma, a bílis amarela e o sangue, mostra a correspondência com os elementos cósmicos, quando os quatro humores equilibram-se entre si, dando vigor ao corpo, mas sofrem oscilações de acordo com as estações do ano e se diversificam com a idade, exacerbando o temperamento. Klibansky cita os antigos para descrever a teoria sobre os humores:

\begin{abstract}
Sunt enim quattuor humores in homine, qui imitantur diversa elementa; crescunt in diversis temporibus, regnant in diversis aetatibus. Sanguis imitatur aerem, crescit in vere, regna in pueritia. Cholera imitatur ignem, crescit in aestate, regnat in adolescentia. Melancholia imitatur terram, crescit in autumno, regnat in maturitate. Phlegma imitatur aquam, crescit in hieme, regnat in senectute. Hi cum nec plus nec minus iusto exuberant, viget homo. ${ }^{11}$
\end{abstract}

\footnotetext{
${ }^{7}$ Para a teoria do enobrecimento da melancolia foi necessário distanciar a melancolia sublime (ila heróica) descrita na sua teoria em De vita Triplice da melancolia corrosiva. Conta ainda a História da Filosofia II de Giovanni Reale e Dario Antiseri que Marcilius Ficinus em De vita triplici expõe a magia natural que desfruta dos benefícios celestes, com meios naturais para a boa saúde do corpo. Ele distingue duas espécies de magia. A segunda magia, que é benéfica, submete as matérias naturais às causas naturais, plasmando-as através de uma lei admirável. Esse artifício tem, portanto, dois caminhos, um é o da pura curiosidade e se satisfaz com a ostentação, o outro caminho pode ser desenvolvido pela medicina conjugada à astrologia. A magia natural de Ficino tem seu fundamento na construção neo-platônica do seu pensamento. Para Ficino que recebeu os votos clericais com 40 anos, as atividades de sacerdote e de filósofo constituem uma só unidade que responde às necessidades espirituais.

8 "Ficine donne même la formule chiffré de la "meilleure" combinaison possible: huit parties de sang, deux de bile jaune, et deux de bile noire (...) reduit encore la proportion de la bile noire dans " 1 'homo sanus et bene compositus"(l'homme sain et bien tempere, dont le mélange est correctement equilibré); le sang, la flegme, la bile jaune et la bile noire sont répartisselon les proportions suivantes: huit, quatre, deux et un”. KLIBANSKY, SAXL, PANOFSKY. Saturne et la Mélancolie. Paris, Gallimard, 1989.

${ }^{9}$ Kierkegaard que reconhecia no riso a presença do divino, vê na melancolia a conseqüência do afastamento de Deus. Já Lutero relaciona a melancolia ao maléfico. Richard Burton na sua anatomia de 1621 utiliza o pseudônimo de Demócrito Júnior para valorizar as teorias daquele pensador.

${ }^{10}$ ARISTOTELES, Ética a Nicomaco in: Os Pensadores, São Paulo, Nova Cultural, 1987, p. 118.

${ }^{11}$ KLIBANSKY, Raymond, SAXL, Fritz,PANOFSKY, Erwin. Saturne et la Mélancolie. Paris. Éditions Gallimard, 1989. p. 31
} 
Os homens que possuem sabedoria prática, diz Aristóteles, são homens de ação 12. É a ausência dessa sabedoria prática para a existência que se traduz em conflito para a estética barroca, ansiando preencher a existência de significação sem saber de que modo. É dessa argamassa que se nutre a representação de Albrecht Dürer interpretada por Benjamin: a percepção unilateral, construída ao longo da história, é explicada na teoria sobre a cegueira da razão que acomete a mentalidade do tempo, analisada pelo novo "estoicismo" que ressurge com a privação da Graça (Gnadensonne). Trata-se do trompe l'oeil, olhar distorcido sobre a realidade, que conduz à apatia e à inércia do coração. A ausência da convicção própria da mentalidade emancipada e do caráter, que será estudado mais tarde por Benjamin no texto Schicksal und Charakter, deixa o espírito da época a mercê do destino.

$\mathrm{Na}$ economia do teatro barroco espanhol que exaltava a virtude, a falta de ação é fatal: a representação estética do personagem Sigismundo em $L a$ vida es sueño de Calderón de La Barca mostra a antítese de um tirano destruído pela inércia do coração na caracterização do drama, onde a indecisão do príncipe não é outra coisa que a acedia, a preguiça para os medievais. ${ }^{13}$ Saturno torna os homens "apáticos, indecisos, vagarosos" e os predispõe ao taedium vitae, confirma a interpretação de Benjamin. Essa predisposição que tem sua explicação na influência astrológica e mereceu destaque especial desde Aristóteles, coincide, no século XVII, com o desenlace gerado pela moral luterana que esvaziara o mundo de sentido, na rejeição de um significado de benesse para a ação humana. Em contraposição a essa idéia, a dissolução provocada por ela origina a tendência à dispersão de signos e o mundo se transforma num grande livro onde a leitura só se completa na tentativa de decifração da existência. Paralela a concepção de destino (Schicksal), aparece o conceito de enigma (Rätsel). O sentimento de desamparo surge meio a profusão de símbolos e se desenvolve na sensação de uma perda da mediação Deus e homem, intensificada com o aparecimento das ciências empíricas simultaneamente ao embotamento da similitude medieval. Cresce a idéia de falta de transcendência, e, por outro lado, a necessidade da graça divina (Gnadensonne) a que o homem perdeu o direito. Mas todo o barroco se dá no espírito da fé cristã, pois o homem ao contrário do que se podia esperar se volta para a espiritualidade. Na moral dos humildes o lema era "fidelidade nas coisas pequenas"". No "fazer o bem" encontrase o apaziguamento. Só o "viver com retidão" pode amenizar o impacto causado pela pressão de um tempo fechado que tem sua consumação na morte, mentalidade deduzida da historiografia inconsciente da produção estética do barroco. Mas o barroco estético espanhol desenvolve, amparado na reflexão cristã, uma saída para o conflito. A técnica desenvolvida por Calderón de la Barca em La vida es sueño supera a dramaturgia alemã dos luteranos Opitz, Gryphius, Lohenstein, Hallmann e Haugwitz, na medida em que lança mão da iniciativa soberana já existente no drama alemão, com relação ao estado de criação (Schöpfungsstand). Diz essa teoria da soberania que é destinada ao maior, entre os seres criados, a ação generosa da compaixão (Mitleid). Ela se exterioriza na máxima de fazer o bem. Porém entre os luteranos onde inexiste esse recurso, é Lohenstein quem leva ao paroxismo a supressão de qualquer discussão eticamente motivada. Benjamin explica esse fenômeno: na arte, "o conteúdo de verdade (Wahrheitsgehalt) que não se encontra nunca na doutrina abstrata, e menos ainda na doutrina moral, mas somente no desdobramento crítico e comentado da própria obra, só

\footnotetext{
${ }^{12}$ ARISTOTELES, Ética a Nicomaco in: Os Pensadores, São Paulo, Nova Cultural, 1987, p. 118.

${ }^{13}$ BENJAMIN, Walter. Origem do Drama Barroco Alemão (trad. Sérgio Paulo Rouanet), São Paulo, Brasiliense, 1984, p.178. Ursprung des deutschen Trauerspiels. Frankfurt. Suhrkamp Verlag, 1977, .

${ }^{14}$ Origem do drama barroco alemão (Trad. Sérgio Paulo Rouanet), Sâo Paulo, Brasiliense, 1984. p. 162. Ursprung des deutschen Trauerspiels. Suhrkamp Verlag. 1977. p.
} 
inclui referências morais de uma forma altamente mediatizada." ${ }^{15}$. Já no teatro espanhol, que não sofre a repercussão das idéias de Lutero sobre a salvação, "o fazer o bem" podia se contrapor à melancolia (taedium vitae) das naturezas mais ricas." Essa idéia estimula a análise filológica de Benjamin a debruçar-se sobre as figurações da cena histórica produzidas pelo Trauerspiel, sobretudo as do tirano e do cortesão. A análise dos temperamentos vem buscar nessas figuras a resposta para o questionamento sobre o conceito de conteúdo de verdade (Wahrheitsgehalt) daquela realidade, descoberta na ambivalência do olhar melancólico, ou seja, na sua predisposição à lucidez: Benjamin comenta sobre um sentido benéfico da distância de Saturno e de uma "razão divina que localiza o astro ameaçador tão longe quanto possível", contemporizando com Giehlow que "se por um lado a meditação do melancólico é compreendida na perspectiva de Saturno, que "como o planeta mais alto e o mais afastado da vida cotidiana e responsável por toda contemplação profunda, convoca a alma para a vida interior, afastando-a das exterioridades, leva-a a subir cada vez mais alto e enfim inspira-lhe um saber superior e o dom profético" ${ }^{16}$. "Quanto à dialética de Saturno", diz Benjamin citando Panofsky e Saxl: "ela exige uma explicação que só pode ser buscada na estrutura interna da concepção mitológica de Cronos...Essa concepção não é dualista apenas com relação à ação externa do deus, mas também com relação a seu destino próprio e pessoal, e isso de forma tão abrangente e tão nítida que poderíamos caracterizar Cronos como um deus dos extremos. Por um lado, ele é senhor da idade de Ouro...por outro, é o deus triste, destronado e humilhado... por um lado, gera (e devora) inúmeros filhos, e por outro está condenado à eterna esterilidade; por um lado é um monstro capaz de ser vencido pela astúcia mais vulgar, e por outro é o deus antigo e sábio, venerado como a inteligência suprema, como $\pi \rho \sigma \mu \eta v \varepsilon \mu \varsigma$

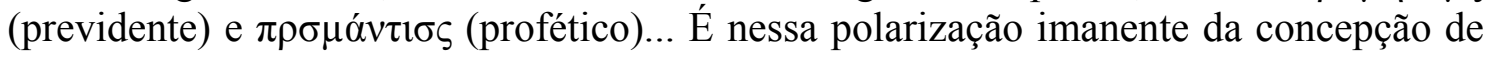
Cronos que o caráter específico da concepção astrológica de Saturno encontra sua explicação definitiva - esse caráter, em última análise, é determinado por um dualismo intenso e fundamental." $\mathrm{O}$ dualismo que subjaz à melancolia ${ }^{17}$ permite uma saída: "a descoberta pode encontrar o autêntico nos fenômenos mais estranhos e excêntricos, nas tentativas mais frágeis e toscas, assim como nas manifestações mais sofisticadas de um período de decadência" ${ }^{18}$, pois a idéia absorve a série de manifestações históricas, e ela faz isso sem utilizar-se do universal do conceito que é retirado da média, mas ela o faz preservando a unidade do singular na totalidade, pois a idéia, segundo Benjamin, é "a configuração em que um extremo se encontra com outro extremo". Com essa óptica, aplicada á estética, a investigação do temperamento melancólico garimpa elementos para a teoria da melancolia na figura do monarca absolutista representado pelo drama alemão. Em Benjamin o sentimento melancólico tanto tem sua origem histórica, quanto orgânica. Sabe-se que para a mentalidade da época barroca representada no Trauerspiel a decadência da história manifestada nas lutas pelo poder se plasmava sobre a degenerescência da physis culpada, instituída pelo cristianismo e distanciada de uma

\footnotetext{
${ }^{15}$ ODBA, p. 128. Ursprung... Opus cit, p. 85

${ }^{16}$ BENJAMIN. Walter. Origem do drama barroco alemão, Opus cit, p. 171

${ }^{17}$ Benjamin cita Panofsky e Saxl: "Como a melancolia, também Saturno, esse demônio das antíteses, investe as almas, por um lado, com preguiça e apatia, por outro, com a força da inteligência e da contemplação; como a melancolia, ele ameaça sempre os que lhe estão sujeitos, por mais ilustres que sejam, com os perigos da depressão ou do êxtase delirante... Para citar Ficino, Saturno raramente influencia temperamentos e destino vulgares, mas pessoas diferentes das outras, divinas ou bestiais, felizes ou acabrunhadas pela mais profunda miséria" BENJAMIN $<$ Walter. Origem do drama barroco alemão, Opus cit, p. 172

${ }^{18}$ ODBA, p. 68. Ursprung ...Opus cit, p. 28.
} 
natura deorum mais pura que se encarnava no Pantheon ${ }^{19}$, o que evidencia o distanciamento do conceito naturalista da antiguidade clássica que determinava, com o mesmo vocábulo physis, a harmonia cósmica. As antíteses do barroco expõem, sem camuflagens, a facies hippocratica da história, ou seja, o aspecto degenerado da marcha das civilizações e elege por isso o cadáver como supremo adereço cênico na representação da história. O trompe l'oeil do barroco reproduz o cenário da história como local de perseguições e luta desenfreada pelo poder. Essa idéia serve de estofo para o Trauerspiel. A realidade interpretada pelo drama tem como microcosmo a corte. Esta constitui o local em que se desenrola a intriga, e os jogos de ambição têm como desfecho a catástrofe histórica. A imanência história-natureza antes de trazer uma solução para o sentimento de desamparo da mentalidade daquela época representava uma fonte inesgotável de metáforas e simbologias para mostrar que desta forma devia se perpetuar o processo histórico, portanto essa realidade não podia contar com a graça da transcendência (Gnadensonne). Sua carência fora motivada pela desmistificação da "caridade", pelo descrédito na ação do homem, interpretada como exteriorização, superficialidade, exacerbando a distância entre o céu e a terra. A iconoclastia luterana esvaziara o mundo ao excluir dele a indulgência da ação caridosa. $\mathrm{O}$ arsenal de antíteses e contradições que margeiam a teoria da melancolia tem seu contraponto na efetivação do "cristianismo incontestado" de que é feito o barroco, onde o homem só encontra a expressão da espontaneidade mais autêntica da fé nas pinceladas do profano. A interpretação do barroco se delineia no circuito do universo exegético da gravura renascentista Melancholie I de Albrecht Dürer, que por várias razões antecipa a contradição da ação humana, motivada pelo conhecimento que se exterioriza no poder e não na sabedoria para a humanidade. Ela encontra seu epígono no sentimento teológico da piedade desesperançada de um cristo morto de Holbein. A investigação de uma disposição encontrada no século XVII para recolher elementos dos estudos renascentistas sobre os quatro humores pode ser igualmente apreciada nos quatro apóstolos de Dürer, que se encontra hoje na Alte Pinakothek de Munique. A riqueza de significados plasmados em cores vibrantes antecipa a recepção da estética barroca. A mesma inclinação para os temas sagrados pode ser observada também na peculiaridade em assimilar, para o absolutismo, remanescentes teológicos presentes na política teocrática. A figura acometida pela melancolia no drama barroco alemão era o príncipe, concebido como um Deus cartesiano, na citação benjaminiana de Atger: Le Prince développe toutes les virtualités de l'Etat par une sorte de création continue. Le Prince est le dieu cartesien transposé dans Le monde politique ${ }^{20}$. O príncipe é "o paradigma do melancólico", diz Benjamin. A melancolia tem a ver com a imposição de decidir. Enquanto o luteranismo conseguiu instilar no povo o rigor da "obediência ao dever", desenvolveu nos grandes a enfermidade da melancolia ${ }^{21}$, porque só a eles cabe decidir sobre o destino dos súditos. Se a fé não conseguia dissipar o sentimento de que a existência era insípida, arrastada na "crença sombria da sujeição do homem ao destino," no entanto, seria ainda a fé a estrutura de "pretextos meramente intercambiáveis" como a pátria, a religião ou a liberdade", ou seja esse sentimento de grandeza interior encontrava brechas ou caminhos para expandir-se no profano. Dessa forma a melancolia tem um laço estreito com a religiosidade da época barroca, onde a espiritualidade não podia se exprimir. Ela foi instilada pelo luteranismo, na medida em que a ação piedosa, motivo da transcendência, era proibida de se manifestar no mundo: "não havia resposta,

\footnotetext{
${ }^{19}$ ODBA, p. 249. Ursprung des deutschen Trauerspiels, p. 202.

20 "O Príncipe desenvolve todas as virtualidades do Estado por uma espécie de criação continua. O Príncipe é o Deus cartesiano transposto ao mundo político”.BENJAMIN. ODBA, Opus cit, p. 119.

${ }^{21}$ BENJAMIN. ODBA, Opus cit. p. 161.
} 
a menos que ela estivesse na moral dos humildes - "fidelidade nas coisas pequenas" ou "viver com retidão" constituía um lema da época para fazer face ao taedium vitae. No teatro espanhol impregnado de religiosidade cristã nem tanto contaminada pelo luteranismo, La vida es sueño de Calderón de La Barca procurava assegurar-se da transcendência, mesmo através de um desvio. Quando Benjamin descobre aí a alegoria, ela constitui a saída para amenizar a dor de sentimento melancólico. A alegoria é o único divertimento "que o melancólico se permite" ${ }^{22}$. E o príncipe é o paradigma desse sentimento de perda. Ninguém como ele absorve com tanta intensidade o sentimento de fragilidade da criatura, na sua condição de mortal. Essa consciência se torna dolorosa na medida em que a dignidade real não é suficientemente grande para distraí-lo dessa recordação que o desperta para a necessidade de ter em torno de si a corte a induzi-lo permanentemente ao esquecimento, pois "o que é um rei além de um homem cheio de misérias", pergunta-se Pascal, concluindo que "a alma não encontra em si nada que a satisfaça. Quando pensa em si mesma não há nada que não a aflija, Isso a obriga a sair de si , procurando na aplicação às coisas perder a recordação de seu verdadeiro estado" 23.

É Shakespeare que consegue "extrair detalhes cristãos da rigidez barroca do melancólico, tão antiestóico, como anticristão, na figura do personagem Hamlet, em que a "auto-absorção melancolia atinge o cristianismo". As palavras de Hamlet exprimem essa inquietação: "Que é um homem, quando distribui seu tempo como bens supremos, apenas entre o sono e a alimentação? Um animal, nada mais. De certo aquele que nos deu tão amplo entendimento, capaz de mover-se entre o antes e o depois, não quis que essa faculdade e essa razão divina enferrujassem sem uso, dentro de nós." ${ }^{24}$. A melancolia é julgamento do mundo. Hamlet sofre por não saber agir. Ele desconhece a ação política. O príncipe que é o responsável pela decisão de proclamar o estado de exceção, se revela, na primeira ocasião, quase incapaz de tomar uma decisão“. Hamlet pode ser sua interpretação mais fiel. A influência de Saturno torna as pessoas apáticas, indecisas, lentas, diz Olgária Matos. O tirano é vítima de sua própria indecisão. A melancolia seiscentista assimila o aspecto histórico de uma razão desiludida. Ela é a correspondência no mundo exterior da perda interior da ordem e harmonia no divino.

Se vimos o que dizem os estudos sobre a melancolia na antiguidade e no renascimento, observemos agora um texto moderno sobre ela: "Para aqueles a quem a melancolia devasta, escrever sobre ela só teria sentido se o escrito viesse da melancolia. Tento lhes falar de um abismo de tristeza, dor incomunicável que às vezes nos absorve, em geral de forma duradoura, até nos fazer perder o gosto por qualquer palavra, qualquer ato, o próprio gosto pela vida. Esse desespero não é uma versão que pressuporia capacidades de desejar e de criar, de forma negativa, claro, mas existentes em mim. Na depressão o absurdo da minha existência, se ela está prestes a se desequilibrar, não é trágico: ele me aparece evidente, resplandecente e inelutável.

De onde vem esse sol negro? De que galáxia insensata seus raios invisiveis e pesados me imobilizam no chão, na cama, no mutismo, na renúncia?

O golpe que acabo de sofrer, essa derrota sentimental ou profissional, essa dificuldade ou esse luto que afetam minhas relações com meus próximos, são em geral o gatilho, facilmente localizável do meu desespero. Uma traição,

uma doença fatal, um acidente ou uma desvantagem, que, de forma brusca, me arrancam dessa categoria que me parecia normal, das pessoas normais, ou que se

\footnotetext{
${ }^{22}$ BENJAMIN. ODBA, Opus cit. p. 207.

${ }^{23}$ BENJAMIN. ODBA. Opus cit. p. 166. Benjamin cita Pascal para mostrar que o rei é rodeado de pessoas que têm um zelo em evitar sua solidão.

${ }^{24}$ BENJAMIN. ODBA. Opus cit. p. 162.
} 
abatem com o mesmo efeito radical sobre um ser querido, ou ainda... quem sabe? A lista das desgraças que nos oprimem todos os dias é infinita... Tudo isso, bruscamente, me dá uma outra vida. Uma vida impossível de ser vivida carregada de aflições cotidianas, de lágrimas contidas ou derramadas, de desespero sem partilha, às vezes abrasador, às vezes incolor e vazio. Em suma uma existência desvitalizada que embora às vezes exaltada pelo esforço que faço para continuá-la, a cada instante está prestes a oscilar para a morte. Morte vingança ou morte liberação, doravante ela é o limite interno, me parece insustentável, salvo nos momentos em que me mobilizo para enfrentar o desastre. Vivo uma morte viva, carne cortada, sangrante, tornada cadáver, ritmo diminuído ou suspenso, tempo apagado ou dilatado, incorporado na aflição...ausente do sentido dos outros, estrangeira, acidental à felicidade eu tenho de minha depressão uma lucidez suprema, metafisica. Nas fronteiras da vida e da morte, às vezes tenho o sentimento orgulhoso de ser a testemunha da insensatez do Ser, de revelar o absurdo dos laços e dos seres." 25.

É evidente que se trata, em Kristeva, de um texto atual para mostrar um contradepressor na psicanálise, bem distanciado da explicação que os antigos possuíam da melancolia e de sua origem orgânica no desequilíbrio entre os quatro humores. A genialidade de Benjamin está em não desmembrar o orgânico do histórico. É este ponto que lhe cita a atualidade. Ele explica a relação nas correspondências entre os astros e o sentimento de desolação da época barroca oriundo em parte de contingências religiosas da bipartição da fé luterana e católica, espaço cindido mais tarde na poesia de Baudelaire distanciando moral cristã e pagã. Mas a análise do Trauerspiel não desmente o elemento orgânico do legado renascentista. Ao contrário do que pensa Benjamin acerca da origem da melancolia na imanência história-natureza, Kristeva relaciona melancolia e depressão. Esse escrito auto-apresentável mencionado pela autora deixa claro que se trata da metodologia da representação evocada pela imagem Melancolie I de Dürer, que antecipa o sentimento barroco da contradição, para a qual a ciência se mostra impotente, segundo a avaliação de Benjamin. No poema de Tscherning Melancholey redet selber interpretado no livro sobre o barroco-Trauerspielbuch, a melancolia se auto-apresenta: "eu, mãe de sangue denso, fardo putrefato pesando sobre a terra quero dizer quem sou, e o que por meu intermédio pode vir a ser. Sou a bílis negra, primeiro encontrada no latim, e agora no alemão, sem ter aprendido nenhum dos dois idiomas. Posso, pela loucura, escrever versos tão bons como os inspirados pelo sábio Febo, pai de todas as artes. Receio apenas que o mundo possa suspeitar de mim, como se eu pretendesse explorar o espírito do inferno. De outra forma, eu poderia anunciar, antes da hora, o que ainda não aconteceu. Enquanto isso permaneço uma poetisa, e canto minha própria história, e o que sou. Devo essa glória a um nobre sangue, e quando o espírito celeste em mim se move, inflamo rapidamente os corações, como uma deusa. Eles ficam então fora de si, e procuram um caminho mais que terrestre. Se alguém viu alguma coisa atrás das sibilas, isso aconteceu graças a mim."

Ao contrário da representação da melancolia em Kristeva, Benjamin valoriza em primeiro lugar o espaço da ambivalência indicado pela melancolia, mas de uma ambivalência que ultrapassa a si mesma, no que ela comporta de aparência, para exibir seu aspecto lúcido e criativo. A sua disposição profética pode ser conciliada à manifestação das soluções. O ruminar (Grübeln) melancólico que tem como apoio a contemplação com seu fôlego incansável leva à decifração de enigmas. A gravura renascentista de Albrecht Dürer reproduz o gesto impotente de uma mulher alada para o vôo. A atmosfera terrificante do cenário é simbolizada pela presença, no desenho, do

\footnotetext{
${ }^{25}$ KRISTEVA, Julia. Sol Negro - Depressão e Melancolia (Trad.Carlota Gomes), Rio de Janeiro, Rocco, 1989. pp. 11-12
} 
planeta Saturno. O pavor transparece no olhar fixo sobre os objetos produzidos pela ciência. A semelhança com o texto do drama barroco vem do aspecto dramático da existência, que substitui o trágico e realça a contradição, onde o cotidiano se transforma em tensão, drama, conflito, luto... Outro elemento barroco do texto da Kristeva é o olhar ao chão, às profundezas da terra, onde inexiste a possibilidade de um aceno para o alto. O absurdo resplandece como uma representação. Ele precisa ser dramatizado, ostentado. Demonstra o nível de inacessibilidade da vida verdadeira, da vida impossível de ser vivida, da existência plena no sentido aristotélico de biós, ou ainda da vida piedosa, na caricatura do barroco, com direito à transcendência. $\mathrm{O}$ absurdo da existência para $\mathrm{o}$ barroco é projetado na encenação, e então capturável no abismo da reflexão, na renúncia à vida real, à felicidade, ou seja, só é evidente na resignação. No texto de Kristeva o desespero é motivado, se origina num acidente, numa desvantagem. Na doutrina da justificação, a reflexão benjaminiana sobre a melancolia causada pela billis negra não tem pouso, não se fixa em nada, consiste numa sensação de perda, de indefinição. $O$ olhar sobre a realidade é torcido (trompe l'oeil), o sentimento de flutuação provocado por essa percepção unilateral desagrega, desorienta, causa vertigem. $\mathrm{O}$ esfacelamento parece ser causado pela disjunção corpo e alma, céu e terra, efêmero e eterno, portanto, na variante metafísica do barroco. Na interpretação de Dürer um quadrado simbolizando júpiter funciona como um talismã contra os efeitos funestos dos predestinados por saturno à tristeza. Um condicionante do enigma da existência? Na figura do príncipe o dilaceramento se anuncia em cada imersão da alma que só encontra o contraponto e o antídoto na instantaneidade do divertissement pascalino, na fruição do instante, no carpe diem, na presença hilariante do bufão, para logo depois se intensificar até a próxima alienação. Está aberto o abismo da contradição humana. Diz ainda Kristeva, coincidindo com o pensamento de Benjamin e encontrando uma saída na ação do homem: "só a mobilização pode evitar o desastre", pois nos dois casos o fardo é o mesmo. No entanto a mentalidade do século XVII permaneceu no impasse, sem descobrir a saída na ação. $\mathrm{O}$ homem é um incógnito, desmerece a reflexão sobre si mesmo. Contraditoriamente o sentimento de desolação intensifica a vida interior, estimula à leitura do mundo e da existência como um enigma, impossível para ele de ser decifrado e cuja motivação é somente o Trauerspiel, em que a palavra Trauer ou seja, luto, em alemão, se conjuga ao Spiel - jogo. Completando o sintagma teremos: artifício para diminuir o impacto da existência lutosa. Dito de forma benjaminiana: "o luto é o estado de espírito em que o sentimento reanima o mundo vazio, sob a forma de uma máscara, para obter, da visão desse mundo, uma compensação enigmática". Kristeva lembra a melancolia na antiguidade e sua determinante do caráter de homens dados a reflexão e aos grandes feitos. Assim a psicanalista aponta o conceito remontando a Aristóteles para encontrar a explicação para sua origem: Nas Problemata (30,I), atribuídas a Aristóteles, a bilis negra (melaina kole) determina os grandes homens. A reflexão (pseudo-)aristotélica aplica-se ao éthos-périton, a personalidade de exceção, à qual a melancolia seria específica. Ao mesmo tempo em que se serviu das noções hipocráticas (os quatros humores e os quatro temperamentos), Aristóteles inova extraindo a melancolia da patologia e situando-a na natureza, mas também e sobretudo fazendo-a decorrer do calor, considerado como princípio regulador do organismo, e da mesotes, interação controlada de energias opostas. Essa noção grega de melancolia hoje nos é estranha: ela supõe uma "diversidade bem dosada" (eukratos anomalia), que se traduz de forma metafórica pela espuma (aphros), contraponto eufórico da bílis negra. „Essa mistura branca de ar (pneuma) e de líquido faz espumar tanto o mar, o vinho, quanto o esperma do homem“. De fato, Aristóteles associa exposição científica e referências míticas, ligando a melancolia à espuma espermática e ao erotismo, e referindo-se explicitamente 
a Dionísio e a Afrodite (VI, 200-203). A melancolia que ele evoca não é uma doença do filósofo, sim sua própria natureza, o seu ethos, diz a psicanalista.

Kristeva explica ainda a ascendência de Aristóteles de uma certa forma, sobre a teoria dos modernos. Com Aristóteles, a melancolia equilibrada pelo gênio, é co-extensiva à inquietação do homem no ser. Ali via-se a antecipação da angústia heideggeriana como Stimmung do pensamento. Nela, Schelling descobre "a essência da liberdade humana", sinal da "simpatia do homem com a natureza". Assim o filósofo seria "melancólico pro superabundância de humanidade" pensa a Kristeva.

São vários os exemplos dados por Aristóteles de que a melancolia supõe o vínculo entre genialidade e loucura. Essa versão do filósofo de Estagira conservou sua influência por muito tempo. Talvez ela estivesse presente ainda no século XVII, levada ao paroxismo para explicar a incapacidade do soberano barroco de lidar com a imposição de decidir (Entschlussfähigkeit) em uma situação de conflito civil religioso, o que inevitavelmente conduzia o reino ao impasse e a pessoa do soberano à loucura ${ }^{26}$.

$\mathrm{Na}$ organização absolutista do Estado do século XVII, a habilidade de saber lidar com os fatos em um estado de exceção (Ausnahmezustand) pertencia à teoria do direito, no sistema jurídico do principado barroco. Portanto a incapacidade de contornar a situação de tumulto desvelaria o lado sombrio da criatura, em outras palavras a fragilidade humana, seu dualismo, cujos caracteres a época considerou excludentes e que tenta expressar na metáfora da face de Janus do monarca. A historiografia inconsciente da obra-de-arte exacerba essa excludência, na configuração do Estadista, uma vez movida pelo Direito Constitucional do século XVII, com a distância, entre a função sacrossanta dada por Deus e a abjeção de sua condição de mortal.

O que é essencialmente importante na análise sobre a melancolia em Origem do drama barroco alemão é a valorização dada aos fins a que se propõe a melancolia, com relação à grande riqueza de intuições antropológicas justas", ou ainda, o apelo, feito pela melancolia, ao outro, que o barroco desconheceu ao ignorar a ambivalência da criatura e com isso o legado para se compreender atualmente o fenômeno da perda do sujeito e de seu espaço, e por outro lado, a possibilidade criativa de revolução, pelo pensamento, que ela instaura.

\footnotetext{
${ }^{26}$ BENJAMIN. Origem do Drama Barroco Alemão. 1984. p. 178
} 


\section{Referências Bibliográficas}

1. ANDERSON. Dag T. "Destruktion/Konstruktion" in: Benjamins Begriffe, (Herausgegeben von Opitz und Wizisla) Frankfurt, Suhrkamp, 2000.

2. ARENDT, Hannah. "Walter Benjamin" in: Menschen in finsteren Zeiten, München, Piper Verlag 1989, S. 197-236.

3. BENJAMIN. Walter. Ursprung des deutschen Trauerspiels. Frankfurt Am Main, Suhrkamp Verlag.

4. -----------Origem do Drama Barroco Alemão (Trad. Sérgio Paulo Rouanet), São Paulo, Brasiliense, 1984.

5. CALLADO, Tereza de Castro. Walter Benjamin - A Experiência da Origem, Fortaleza, Eduece, 2006.

6.------------------------------- “ $O$ comportamento ex-officio do estadista na teoria $d a$ soberania em Origem do Drama Barroco Alemão in: Ética e Metafísica, Fortaleza, Eduece, 2007.

7. KLIBANSKY. Raymond, PANOFSKY, Erwin, SAXL, Fritz. Saturne et la Mélancolie, Éditions Gallimard, Paris, 1989.

8. KRISTEVA, Julia, Soleil Noir-Dépression et Mélancolie, Éditions Gallimard, 1987.

9. LINDNER, Burckhardt, Benjamin Handbuch - Leben - Werk - Wirkung, Verlag J. B. Metzler Stuttgart. Weimar, 2006.

10. MATOS, Olgária. Os arcanos do inteiramente outro, São Paulo, Brasiliense, 1989.

11. MOSES. Walter. "Spätzeit" in: Narrativas da Modernidade (Org. Wander Melo Miranda), Belo Horizonte, Autêntica, 1999.

12. SONNTAG, Susan, "Sob o Signo de Saturno" in: Sob o Sgno de Saturno, São Paulo, L\&PM, 1986, pp. 85-104. 